Niniejsza publikacja jest dostępna na licencji Creative Commons. Uznanie autorstwa-Użycie niekomercyjne-Bez utworów zależnych 3.0 Polska. Pewne prawa zastrzė̇one na rzecz autora. Zezwala się na wykorzystanie publikacji zgodnie z licencja - pod warunkiem zachowania niniejszej informacji licencyjnej oraz wskazania autora jako właściciela praw do tekstu. Treść licencji jest dostępna na stronie: http://creativecommons.org/licenses/by-nc-nd/3.0/pl/

Lingwistyka Stosowana 19: 4/2016, 91-103

\author{
Mariusz MELA \\ Virginia SCHULTE \\ Uniwersytet Warszawski
}

\title{
Jak piękny jest ludzki głos! Techniki wizualizacji, mierzenia i deskrypcji ludzkiego głosu
}

\begin{abstract}
:
Beauty of the Human Voice. Modern Methods of Visualising, Measuring and Describing the Human Voice

The paper is concerned with modern techniques of measuring, visualising and describing the human voice as implemented in the Laboratory of Multimodal Communication at Warsaw University. According to the authors, human communication is a multimodal system of expression and comprises vocal, verbal and paraverbal elements. Such an approach to human communication requires the development of special methods for analysing linguistic data. In the paper, some basic phonetic terms having been explained, it will be shown how vocal displays can be analysed using the computer programme Praat for the purposes of investigating pronunciation mistakes in intercultural communication. In the last part of the paper, GAT2 conventions for the transcription of selected paraverbal phenomena will be listed and an example transcription will be provided.
\end{abstract}

\section{Wstęp}

W artykule przedstawiony został zarys badań prowadzonych w Laboratorium Komunikacji Multimodalnej (LAKOM) działającym w IKSI WLS. Ponadto omówione zostały techniki wizualizacji, mierzenia i deskrypcji ludzkiego głosu, które w laboratorium LAKOM odbywają się przy zastosowaniu programu do analizy fonetycznej Praat. Wcześniej jednak przypomniane zostały podstawowe pojęcia z zakresu fonetyki oraz mechanizm powstawania ludzkiego głosu. ${ }^{1}$

\section{Laboratorium LAKOM}

Laboratorium Komunikacji Multimodalnej jest jednostką badawczą Instytutu Komunikacji Specjalistycznej i Interkulturowej Uniwersytetu Warszawskiego i zajmuje się multimodalną analizą interakcji komunikacyjnych przebiegających twarzą w twarz i

\footnotetext{
${ }^{1}$ Niniejszy artykuł stanowi pisemną wersję prezentacji, która odbyła się w ramach obchodów 200-lecia istnienia Uniwersytetu Warszawskiego przez Wydział Lingwistyki Stosowanej w dn. 3 marca 2016 r. Autorzy chcieliby podziękować pani prof. dr hab. Silvii Bonacchi za pomoc $\mathrm{w}$ przygotowaniu artykułu.
} 
komunikacją odbywającą się za pośrednictwem Internetu (computer-mediated communication, CMC). LAKOM pomyślane jest jako platforma zrzeszająca studentów i młodych naukowców.

Stworzenie Laboratorium podyktowane było przekonaniem, że rzeczywistego języka ludzkiego nie da się ograniczyć jedynie do środków werbalnych, jako że rzeczywisty język ludzki jest multimodalnym systemem ekspresji, łączącym w sobie werbalne, parawerbalne i niewerbalne elementy. Do badań nad tak pojmowaną komunikacją wykorzystywane są w Laboratorium następujące programy komputerowe: Folker (transkrypcja nagrań), Praat (analiza fonetyczna), oraz Elan (całościowa analiza multimodalna nagrań video). Sposób zastosowania tych programów został opisany w kilku publikacjach, m.in. Bonacchi/ Mela (2015), Bonacchi/ Mela (2016).

$\mathrm{Na}$ stronie internetowej jednostki, znajdującej się pod adresem www.lakom.uw.edu.pl, znaleźć można informacje dotyczące bieżących wydarzeń, uzyskać dostęp do wymienionych programów komputerowych do transkrypcji, analizy fonetycznej i multimodalnej nagrań, linki do stron internetowych oraz wirtualną bibliotekę.

\section{Jak powstaje ludzki glos?}

Proces powstawania ludzkiego głosu jest bardzo skomplikowanym zjawiskiem akustycznym i mechanicznym. Niezbędna jest przy tym możliwość tworzenia dźwięku. Umiejętność tworzenia dźwięku oraz przekształcania tonu krtaniowego w ton artykułowany stanowi jedną z największych zdobyczy ewolucji człowieka, która odróżnia go od zwierząt. Poniższa ilustracja przedstawia schematyczny wygląd i położenie organów produkcji mowy w organizmie (Schemat 1):

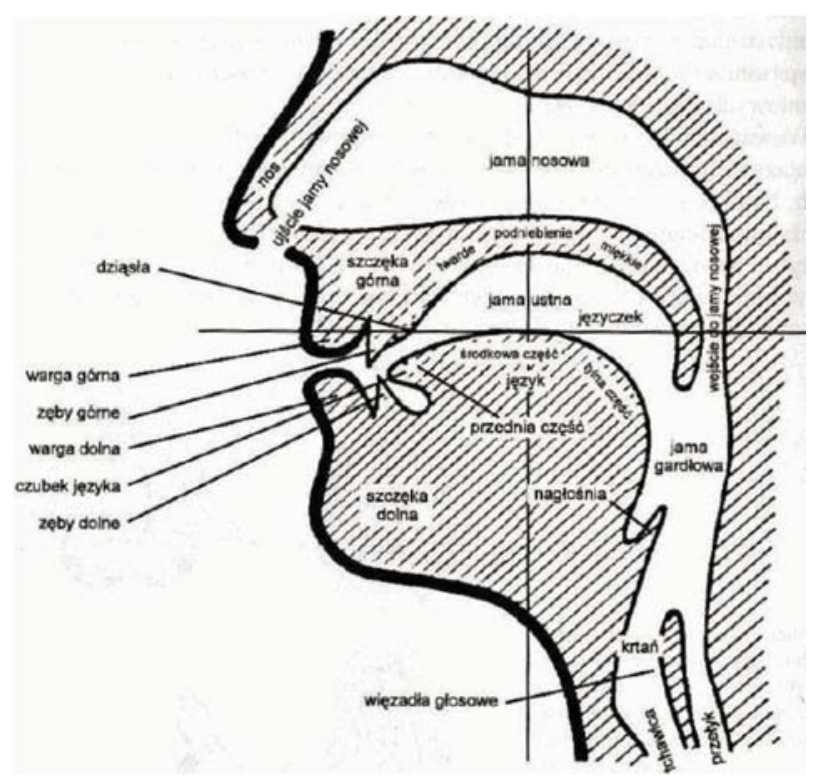

Schemat 1. Schemat rozmieszczenia narządów mowy (zob. Wieczorkiewicz 1977: 23) 


\subsection{Organy produkowania dźwięku}

W dużym uproszczeniu można powiedzieć, że wyjątkowość ludzkiego głosu polega na tym, że jego powstawanie jest wynikiem współpracy elementu ,pobudzajacego" (strumień wydychanego powietrza powoduje drganie fałd głosowych), ciała wibracyjnego (tj. fałd głosowych - ich długość, napięcie i grubość decydują o wysokości i jakości dźwięku) i rezonatorów ruchomych (jama ustna, jama nosowa i klatka piersiowa). Elementy te składają się na ludzki aparat głosowy. Generatorem drgań akustycznych w organizmie jest krtań (larynx).

Produkowanie dźwięku (fonacja) przebiega w kilku fazach:

1) Pierwszą fazą jest zgromadzenie $w$ płucach dostatecznie dużej ilości powietrza;

2) Następnie mięśnie oddechowe powodują wydech, który wprawia struny głosowe w drganie;

3) Pod wpływem wzrostu ciśnienia szpara głośni otwiera się w okolicy podgłośniowej (poniżej fałdów głosowych);

4) Następuje rozwarcie szpary głośni, przez którą przepływa powietrze. Ciśnienie podgłośniowe spada, a fałdy głosowe powracają do pierwotnego położenia;

5) Powtarzające się wielokrotnie cykle rozwierania i zwierania fałdów głosowych powodują powstawanie drgań powietrza (dźwięku);

6) Powstaje ton krtaniowy. Ton krtaniowy, przechodząc przez rezonatory (czyli jamę ustną i nosową), nabiera odpowiednich właściwości i przekształca się w ton artykułowany (głos, mowa). Proces ten odbywa się przy kontroli słuchu.

\subsection{Produkcja i podzial samoglosek}

Samogłoski odpowiadają za akcent wyrazowy oraz barwę głosu. Jako że artykulacja samogłosek nie wymaga zwarcia narządów artykulacyjnych, mamy możliwość przedłużenia czasu ich trwania, co nadaje naszej mowie śpiewności. W zależności od ruchów języka i jego pozycji w jamie ustnej można wyróżnić następujące samogłoski w języku polskim: poziome ruchy języka: (1) samogłoski przednie (i, y, e), samogłoski centralne (a), samogłoski tylne $(\mathrm{o}, \mathrm{u})$; (2) pionowe ruchy języka: samogłoski wysokie (u, i, y), samogłoski średnie (e, o), samogłoski niskie (a) (podział ten ilustruje schemat 2).

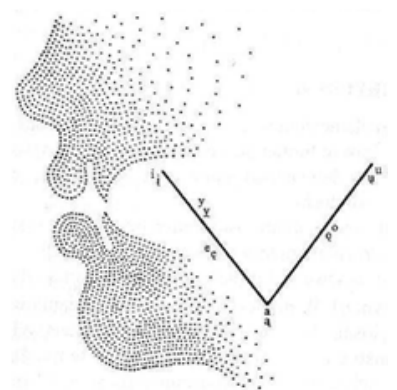

Schemat 2. Tzw. trójkąt samogłoskowy uwzględniający samogłoski języka polskiego (zob. Lombardo 1988 w: „Emisja głosu”: 9) 


\subsection{Produkcja i podział spólglosek}

O ile w przypadku samogłosek powstały w krtani dźwięk bez przeszkód wydostaje się na zewnątrz, to przy wymawianiu spółgłosek dźwięk napotyka na przeszkodę będącą wynikiem zwarcia narządów artykulacyjnych. Ze względu na udział strun głosowych spółgłoski dzielą się na dźwięczne i bezdźwięczne.

Dźwięczność (sonoryczność) związana jest z pracą więzadeł głosowych. Głoski dźwięczne powstają przez wymuszenie drgań więzadeł przy produkcji dźwięku, natomiast głoski bezdźwięczne wymawiane są bez drgań więzadeł głosowych. Spółgłoski dźwięczne i bezdźwięczne układają się w pary: b-p, d-t, g-k, dż-cz, w-f, z-s. Spółgłoski, które nie tworzą par, zaliczamy do półotwartych: $\mathrm{m}, \mathrm{n}$ (nosowe), $1,1, \mathrm{r}$.

Inny podział spółgłosek zależny jest od tego, które narządy artykulacyjne biorą udział $\mathrm{w}$ ich tworzeniu. W tym sensie spółgłoski dzielimy na: (a) spółgłoski wargowe (labialne), (b) spółgłoski zębowe (dentalne), (c) spółgłoski dziąsłowe (alweolarne), (d) spółgłoski podniebienne (palatalne, twardopodniebienne), (d) spółgłoski miękkopodniebienne (welarne), (e) spółgłoski języczkowe (uwularne), (f) spółgłoski gardłowe (faryngalne), (g) spółgłoski krtaniowe (laryngalne).

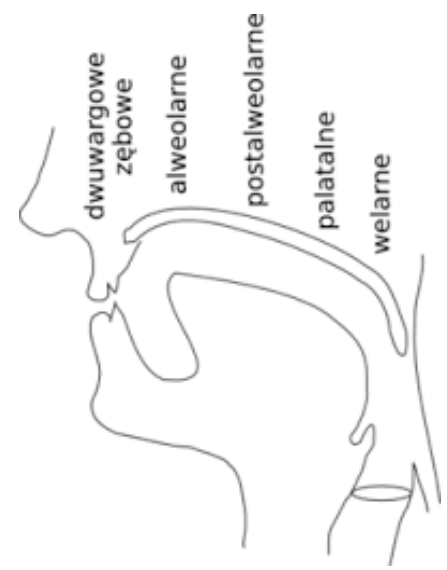

Schemat 3. Podział spótgłosek ze względu na miejsca artykulacji ${ }^{2}$

Ze względu na stopień zbliżenia narządów mowy w czasie wyróżnia się: (a) spółgłoski zwarto-otwarte (nosowe, drżące (wibranty), boczne (lateranty), aproksymanty), (b) spółgłoski zwarte (zwarto-wybuchowe, plozywne), (c) spółgłoski zwarto-szczelinowe (zwarto-trące, afrykaty), (d) spółgłoski szczelinowe (trące, frykatywne), (e) spółgłoski półotwarte (sonanty).

Jakość głosu zależy od typu fonacji. Nastawienie i wygaśnięcie fonacji, tj. sposób, w jaki więzadła głosowe są wprawiane w drgania, może być: (a) miękkie (więzadła płynie zsuwają się lub rozsuwają), (b) twarde (polega na szybkim zwarciu więzadeł, głos ma brzmienie eksplozyjne, powstaje szorstka/sztywna dźwięczność, ang. stiff voice), (c) chuchające (szpara głośni nie jest całkowicie domknięta - ma miejsce

\footnotetext{
${ }^{2}$ (Źródło: https://pl.wikipedia.org/wiki/Fonologia_j\%C4\%99zyka_szwedzkiego\#/media/File:Crossection.png. [Pobrano 25.08.2016])
} 
fonacja chuchająca lub szeptowa dźwięczna, ang. breathy voice), (d) Creaky voice artykulacja krtaniowa (nieregularne zsuwanie się lub rozsuwanie więzadeł, glotalizacja).

Lingwista może wykorzystać i interpretować różne dane fizyczne dla celów badawczych. Ma on tutaj do dyspozycji kilka programów do analizy akustycznej i fonetycznej, jak na przykład Praat. W dalszej części artykułu opisane zostaną niektóre funkcje tego programu.

\section{Analiza fonetyczna przy pomocy programu Praat}

Autorami programu „Praat: doing phonetics by computer” są Paul Boersma and David Weenink - naukowcy z Instytutu Fonetyki Uniwersytetu w Amsterdamie. Program można pobrać ze strony http://www.fon.hum.uva.nl/praat/, gdzie znajduje się również opis innych jego funkcji.

Jako nieprofesjonalni fonetycy wykorzystujemy wybrane funkcje programu odpowiadające naszym potrzebom badawczym. Analizie poddajemy mianowicie: cechy segmentalne (głoski, sylaby) oraz suprasegmentalne (prozodia - rytm, intonacja, akcent). Program umożliwia jednak profesjonalną analizę fonetyczną, tj. analizę głośności (w dB), tempa (sekundy, milisekundy), czasu trwania (s), frekwencji podstawowej $(\mathrm{Hz})$, intensywności, formantów i in.

\subsection{Korzystanie z programu Praat - oscylogram i spektrogram}

Po otwarciu programu pojawiają się dwa okna - Praat Objects i Praat Picture. Za pomocą pierwszego z nich można nagrać i zapisać dźwięk mono lub stereo w postaci pliku *.wav, w drugim zaś możemy otworzyć nagranie, które ukaże się w postaci spektrogramu i oscylogramu.

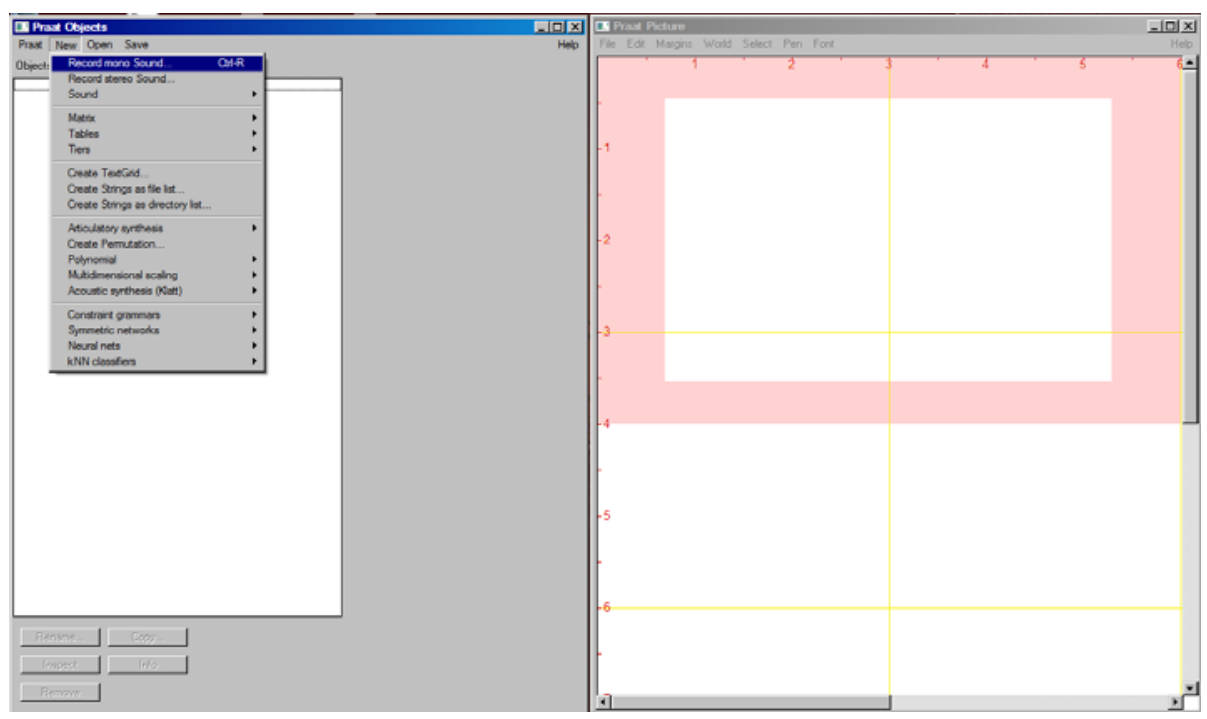

Schemat 4. Widok okien Praat Objects i Praat Picture. 
Po nagraniu dźwięku możemy zobaczyć jego właściwości na spektrogramie (górna część okna) oraz oscylogramie (poniżej spektrogramu), który ilustruje zmiany amplitudy dźwięku oraz jego częstotliwość w czasie (Schemat 5). Ciemniejsze pola oscylogramu oznaczają wyższą amplitudę dźwięku, jaśniejsze niższą. Na oscylogramie widoczny jest także kontur intonacyjny nagranego dźwięku (widoczny w postaci niebieskiej linii). Na podstawie oscylogramu możemy ponadto określić czas trwania dźwięku (w sekundach), jego intensywność ( $\mathrm{w} d \mathrm{~B}$, widoczna w programie w postaci żółtej linii), źródło dźwięku, frekwencję podstawową F0 (tj. wysokość dźwięku w Hz - jest ona różna dla kobiet i mężczyzn i waha się odpowiednio w przedziale 150-450 $\mathrm{Hz}$ dla kobiet oraz 75-300 Hz dla mężczyzn) - frekwencję podstawową możemy zmierzyć sami lub skorzystać z odpowiedniej funkcji programu. Poniższe grafiki ilustrują głoski [i], [e] oraz [a] - a zatem głoski przednią, średnią oraz niską - na spektrogramie oraz oscylogramie (Schematy 5-7).

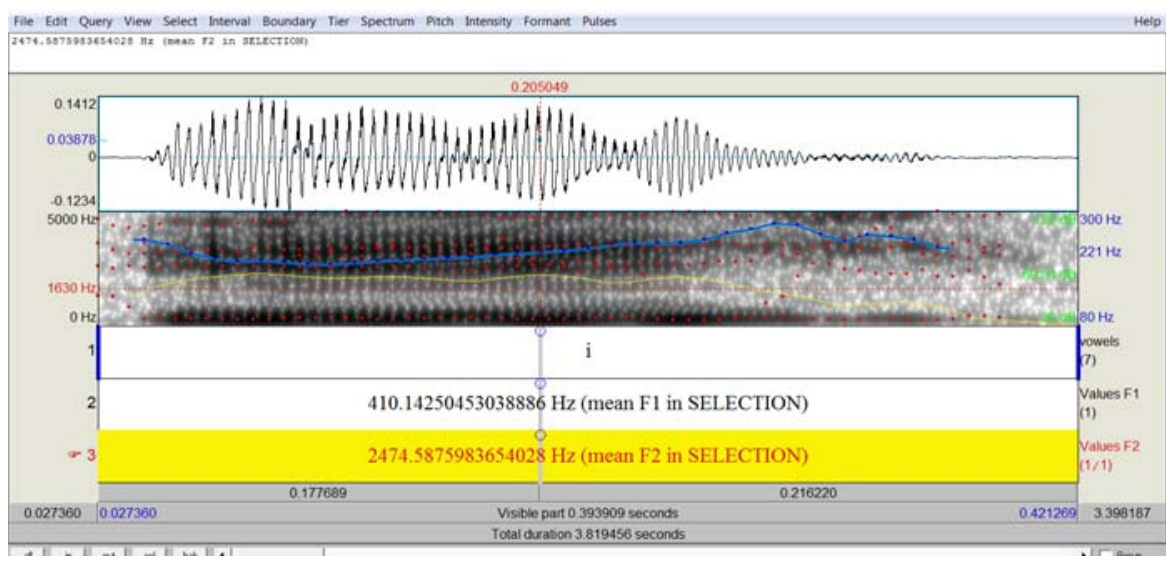

Schemat 5. [i] na oscylogramie i spektrogramie.

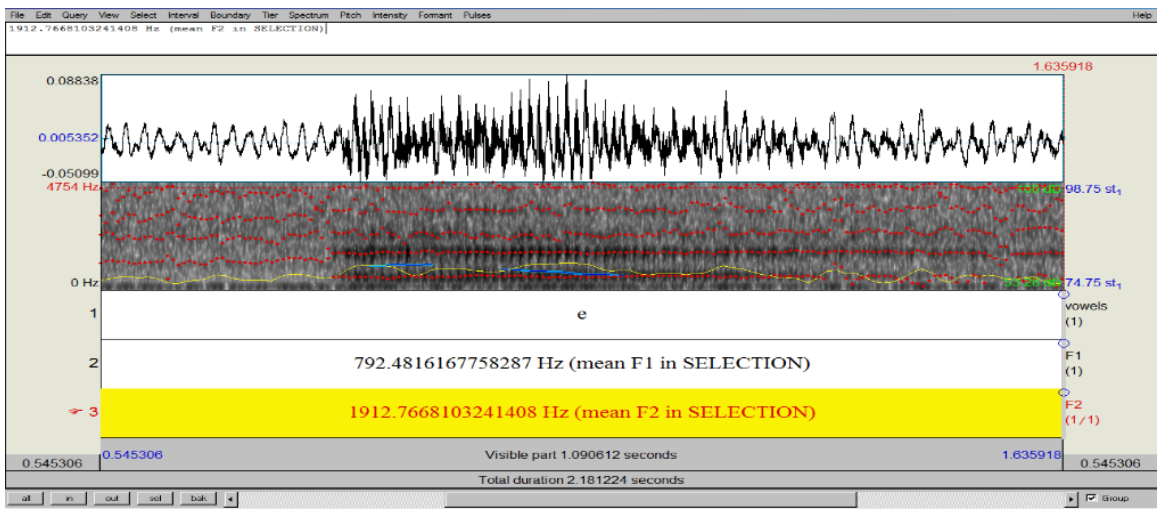

Schemat 6. [e] w sygnale. 


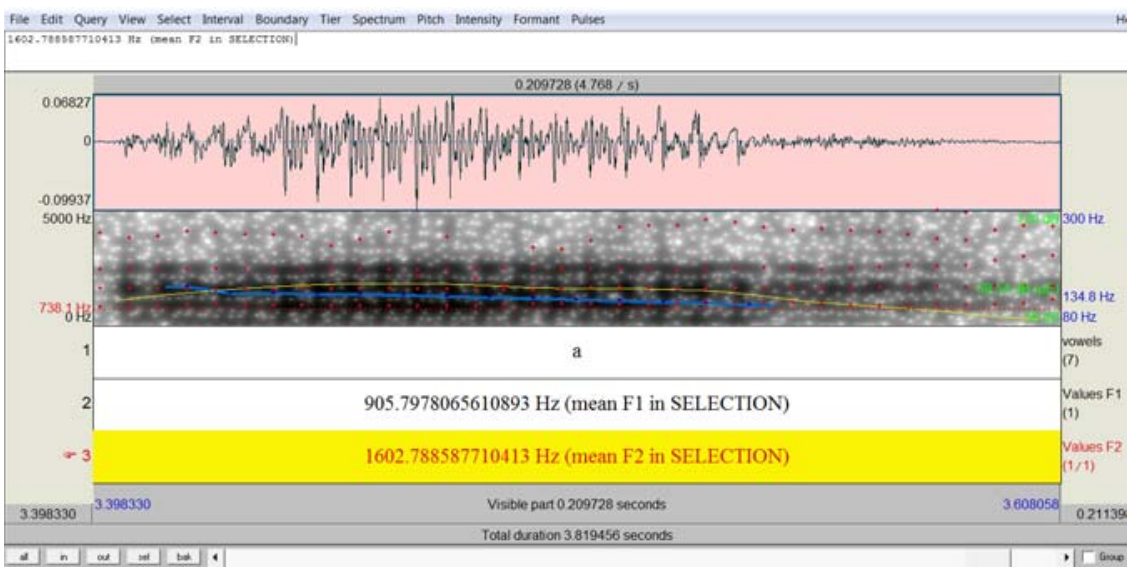

Schemat 7. [a] w sygnale.

Oprócz wspomnianych właściwości oscylogram umożliwia również zbadanie częstotliwości formantów. Formanty to różne składowe energii włożonej w wyprodukowanie dźwięku, powstające wskutek rezonansów wnęk jamy ustnej. Ich wartości (w Hz) zależą od pozycji i ruchów aparatu artykulacyjnego. Najważniejszymi formantami są F1 i F2. Na oscylogramie widoczne są w postaci czerwonych punktów.

\subsection{Transkrypcja i anotacja}

W tej części pokazane zostanie, w jaki sposób program Praat może zostać wykorzystany do transkrypcji i anotacji nagranego materiału. Jako część badań interkulturowych możemy m.in. analizować błędy/ odstępstwa fonetyczne u obcokrajowców. Dla przykładu przeanalizujmy wyraz ,żyleta”, w którym znajdują się samogłoski y - e a, a zatem samogłoski przednia, średnia i niska. Jeśli porównamy ich realizację w wyrazie ,żyleta” (Schemat 8) z realizacjami przedstawionymi na schematach 5-7, to zauważymy, że realizacje te znacznie się od siebie różnią. Wynika to $\mathrm{z}$ faktu sąsiadowania tych samogłosek ze spółgłoskami ż, l, t. Ponadto samogłoska przednia [y] wymówiona została przez obcokrajowca jako inna samogłoska przednia, mianowicie [i].

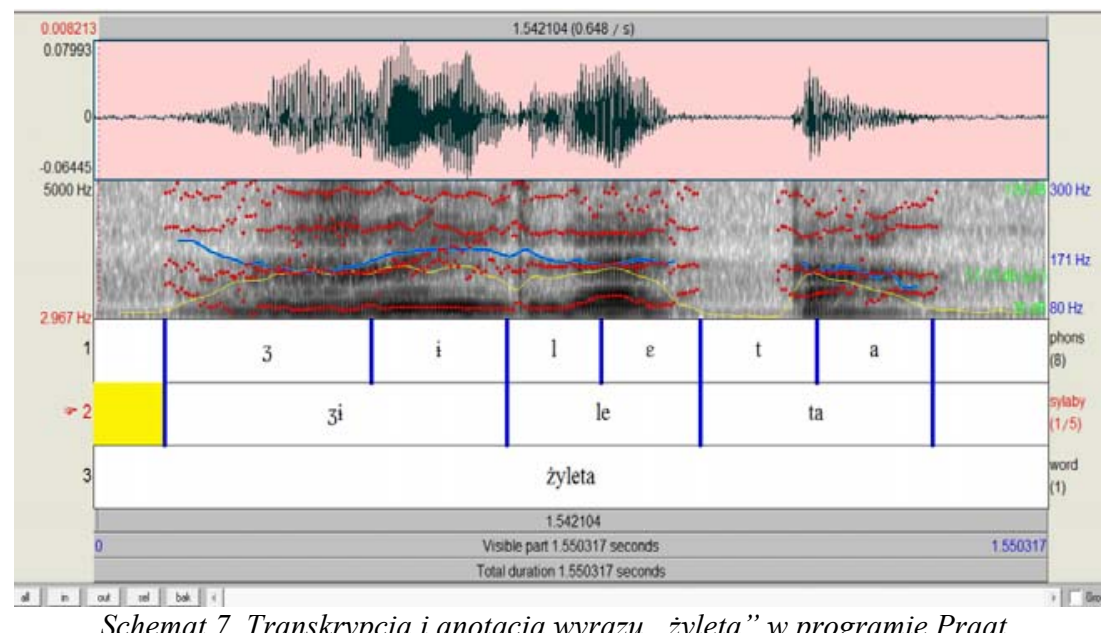

Schemat 7. Transkrypcja i anotacja wyrazu ,żyleta” w programie Praat. 
Po zaznaczeniu interesującego nas fragmentu możemy określić, jakie właściwości chcemy poddać anotacji. W naszym przypadku przeprowadziliśmy anotację sylab, a następnie sylaby podzieliliśmy na głoski. Posłużyliśmy się przy tym znakami międzynarodowego alfabetu fonetycznego IPA.

Tak przygotowaną anotację można zapisać w postaci pliku graficznego. Wadą programu jest jednak niska pamięć, co sprawia, że nie można zobaczyć całości anotacji, lecz jedynie przejrzeć ją fragment po fragmencie.

Program Praat został w bardzo ciekawy sposób wykorzystany przez S. Köser i M. Melę (2016, w druku) ${ }^{3}$ do analizy kulturologicznej sygnałów słuchacza w językach polskim i niemieckim. Autorzy dzięki analizie kilkunastu przypadków użycia najpopularniejszych sygnałów słuchacza (po dwa dla każdego języka) wykazali między innymi, że sygnał „mhm” w tej samej funkcji (zachęcania mówcy do kontynuowania wypowiedzi, tzw. funkcja continuer, zob. Gardner 2001) ma różny kontur intonacyjny w każdym z analizowanych języków (wznoszący w j. polskim, płaski w j. niemieckim). Zastosowanie wznoszącego konturu intonacyjnego sygnału „mhm” ma w języku niemieckim inną funkcję i świadczy o rozdrażnieniu słuchacza - wyniki badań tego typu mogłyby zostać wykorzystane w dydaktyce języków obcych.

\section{Graficzne sposoby przedstawiania zjawisk prozodycznych - GAT2}

Niektóre zjawiska fonetyczne można w transkrypcji przedstawić za pomocą symboli. Pomocny jest tutaj system GAT2 (Gesprächsanalytisches Transkriptionssystem) opracowany w Instytucie Języka Niemieckiego w Mannheim (zob. Selting et al. 2009). Stosowanie konwencji GAT2 może odbywać się na trzech poziomach zaawansowania: transkrypt minimalny (Minimaltranskript), transkrypt podstawowy (Basistranskript), tranksrypt szczegółowy (Feintranskript). Dla lingwisty najbardziej przydatne są dwa ostatnie typy, ponieważ uwzględniają transkrypcję największej liczby parawerbalnych zjawisk; transkrypt minimalny może zaś z powodzeniem być stosowany na przykład w naukach społecznych, psychologii itp., ponieważ zawiera konwencje zrozumiałe dla nie-lingwistów. Poniżej przedstawione są wybrane symbole konwencji GAT2 (por. Selting et al. 2009):

\section{Mówienie symultaniczne}

[ ] nakładanie się wypowiedzi; []

\section{Wdech i wydech}

${ }^{\circ} \mathbf{h} / \mathbf{h}^{\circ}$ wdech i wydech trwające ok. 0.2-0.5 sek.;

${ }^{\circ} \mathbf{h h} / \mathbf{h h} \mathbf{h}^{\circ}$ wdech i wydech trwające ok. 0.5-0.8 sek.;

${ }^{\circ} \mathbf{h h h} / \mathbf{h h h}{ }^{\circ}$ wdech i wydech trwające ok. 0.8-1.0 sek.

\footnotetext{
${ }^{3}$ Por. Mela, M./ S. Köser (w druku): Polish and German feedback signals in dyadic interactions: A culturological and phonetic analysis, (w:) Lingwistyka Stosowana/Applied Linguistics 2017.
} 


\section{Pauzy}

(.) mikropauza (do ok. 0.2 sek.);

(-) krótka pauza (ok. 0.2-0.5 sek.);

(-) pauza średniej długości (0.5-0.8 sek.);

(---) dłuższa pauza (0.8-1.0 sek.);

(0.5) pauza trwająca od ok. 0.5 do 2.0 sek.

\section{Pozostałe konwencje segmentalne:}

oraz_yy przesunięcia w obrębie jednostki;

hm mm yy pauzy wypełnione;

?nie wyraz wypowiadany przy zastosowaniu zwarcia krtaniowego.

\section{Śmiech}

haha hehe hihi sylabiczny śmiech;

((śmieje się)) opis zdarzenia w trakcie wypowiedzi;

$<<$ śmiejąc się > > oznaczenie wypowiadanego fragmentu przy jednoczesnym zdarzeniu parawerbalnym;

$<<:-$ ) $>$ taaak $>$ tzw. ,smile voice“.

\section{Sygnały słuchacza}

hm hm_hm no nie tak - sygnały jedno- i dwusylabowe.

\section{Pozostałe konwencje}

((kaszle)) para- i pozajęzykowe zdarzenia i działania (tutaj: kaszel);

$<<$ kaszląc $>>$ para- i pozajęzykowe zdarzenia i działania towarzyszące mowie;

<<zaskoczony> naprawdę?> interpretacja emocji towarzyszących wypowiadanemu fragmentowi;

( ) fragment niezrozumiały;

$(\mathbf{x x x}),(\mathbf{x x x} \mathbf{x x x})$ jedna lub dwie niezrozumiałe sylaby;

(chyba tak) przypuszczalne brzmienie wypowiedzi.

\section{Przebieg wypowiedzi}

= szybkie, bezpośrednie przejście do kolejnej wypowiedzi lub segmentu (tzw. latching).

\section{Pozostałe konwencje segmentalne:}

: przedłużenie samogłoski w wyrazie o ok. 0.2-0.5 sek.;

:: przedłużenie samogłoski w wyrazie o ok. 0.5-0.8 sek.;

::: przedłużenie samogłoski w wyrazie o ok. 0.8-1.0 sek.

\section{Intonacja na końcu fraz intonacyjnych}

? wznosząca;

, lekko wznosząca;

- równomierna;

; lekko opadająca;

- opadająca. 
Intonacja akcentów wyrazowych:

'TAK opadająca;

'TAK wznosząca;

-TAK równomierna;

^TAK wznosząco-opadająca;

TAK opadająco-wznosząca.

Rejestr wypowiadanego dźwięku:

$<<\mathbf{t}>>$ niski rejestr;

$<<\mathbf{h}>>$ wysoki rejestr.

Akcent:

AKcent akcent fokusowy; telekomuniKACja akcent poboczny;

AK!cent! dodatkowy silny akcent.

Głośność oraz zmiany tempa wypowiedzi:

$<<\mathbf{f}>>$ forte, głośno;

$<<\mathbf{f f}>>$ fortissimo, bardzo głośno;

$<<$ p $>>$ piano, cicho;

$<<$ pp $>>$ pianissimo, bardzo cicho;

$<<$ all $>>$ allegro, szybko;

$<<$ len $>>$ lento, wolno;

$<<$ cresc $>>$ crescendo, coraz głośniej;

$<<$ dim $>>$ diminuendo, coraz ciszej;

$<<$ acc $>>$ accelerando, przyspieszając;

$<<$ rall $>>$ rallentando, zwalniając.

Jakość głosu oraz sposób artykulacji:

$<<$ creaky $>>$ laryngalizacja;

$<<$ szepcząc $>>$ inny sposób artykulacji (tutaj: mówienie szeptem).

Nagłe zauważalne skoki intonacji:

$\uparrow$ niewielki skok w górę;

$\downarrow$ niewielki skok w dół;

$\uparrow \uparrow$ duży skok w górę;

$\downarrow \downarrow$ duży skok w dół.

Poniższa transkrypcja ilustruje zastosowanie konwencji GAT2 w praktyce. Jest to rozmowa pomiędzy Moniką Olejnik a Arturem Zawiszą w programie „Kropka nad i” z dn. 12.11.2012 r. Tematem rozmowy były zamieszki podczas obchodów Dnia Niepodległości dzień wcześniej.

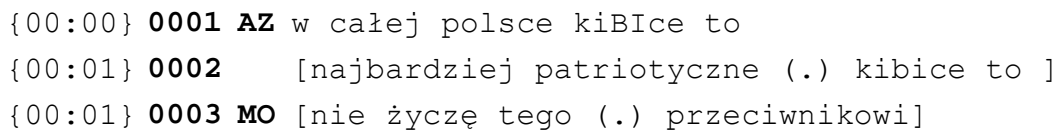




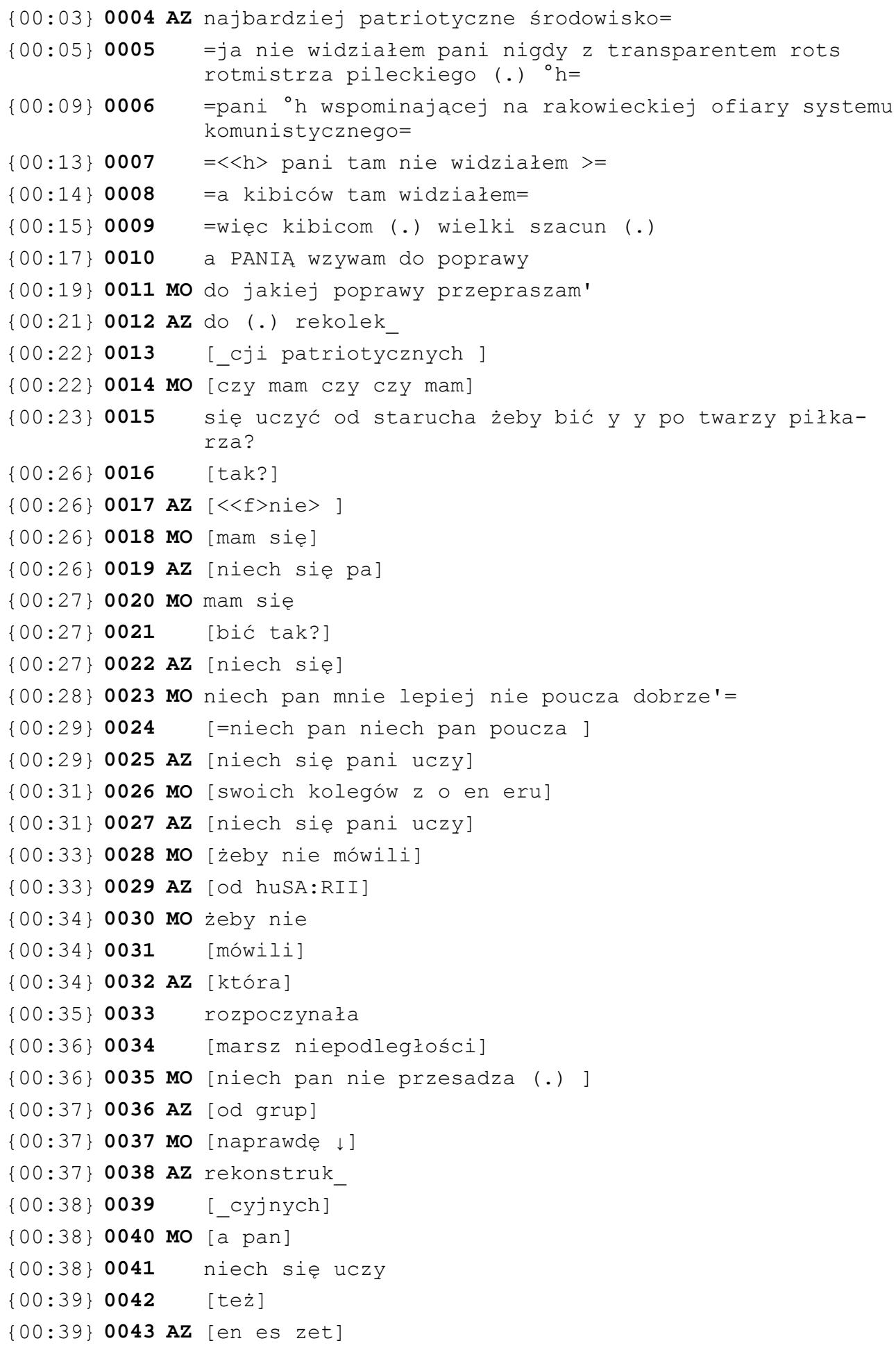




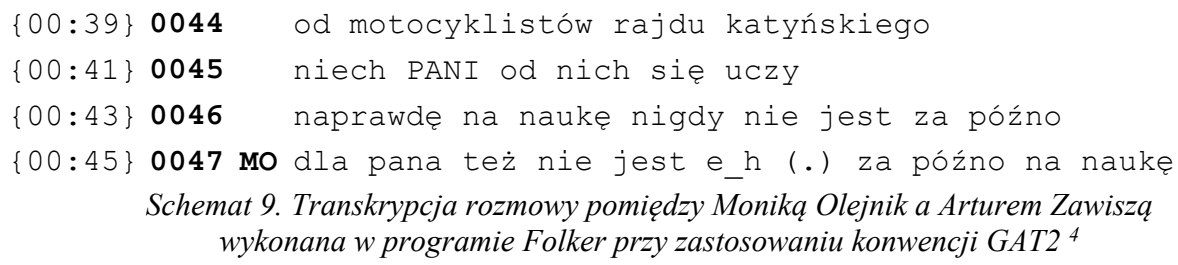

Konwencje GAT2 są skonstruowane tak, że danemu zjawisku fonetycznemu odpowiada tylko jeden symbol. Dotyczy to wszystkich trzech stopni zaawansowania transkrypcji (transkrypt minimalny, podstawowy i szczegółowy). Niektóre z tych konwencji mają charakter interpretacyjny (np. <<zaskoczony $>>$ ). Dzięki wykorzystaniu programu Praat badacz jest w stanie określić, jakie cechy fonetyczne składają się na dany efekt zinterpretowany w ten sposób. Wprawdzie GAT2 nie uwzględnia znaków alfabetu fonetycznego, może on jednak zostać wprowadzony w transkrypcji, jeśli badacz uzna to za konieczne (np. w przypadku wyrazów pisanych alfabetem innym niż laciński).

\section{Wnioski}

Konwencje GAT2 stanowią ciekawy i niezwykle przydatny sposób graficznego zilustrowania zjawisk parawerbalnych. Ma to szczególne znaczenie, gdy badacz nie ma dostępu do nagrania dźwiękowego interakcji. Dzięki trzem stopniom zaawansowania transkrypcji z użyciem konwencji GAT2 znajdują one zastosowanie także poza lingwistyka. Program Praat zaś z powodzeniem może być implementowany w badaniach nad komunikacją twarzą-w-twarz, akwizycją językową, komunikacją interkulturową, w dydaktyce języków obcych $\mathrm{i}$ in. W badaniach nad komunikacją twarzą-w-twarz analiza fonetyczna połączona $\mathrm{z}$ analizą displayu kinetycznego i werbalnego umożliwi całościową analizę komunikacji międzyludzkiej oraz zbadanie zależności między elementami werbalnymi, kinetycznymi i fonetycznymi.

\section{Bibliografia}

Bonacchi, S./ M. Mela (2015), The use and interoperability of computer programmes Folker, ELAN and Praat for multimodal linguistic annotation, (w:) S. Bonacchi/ M. Karpiński (red.), Journal of Multimodal Communication Studies, 2/2015, 18-29.

Bonacchi, S./ M. Mela (2016), Multilingwalny (polsko-niemiecki) korpus języka mówionego MCCA dla celów analizy kulturologicznej i suprasegmentalnej (nie)grzeczności językowej, (w:) E. Gruszczyńska/ A. Leńko-Szymańska (red.), Polskojęzyczne korpusy równoległe. Warszawa, 181-195.

Gardner, R. (2001), When Listeners Talk: Response Tokens and Listener Stance. Amsterdam/ Philadelphia.

\footnotetext{
${ }^{4}$ Nagranie zamieszczone jest pod adresem: http://www.tvn24.pl/kropka-nad-i,3,m/niesiolowski-zule-bili-policje-zawisza-pan-powiedzial-juz-wszystko,288294.html, 00:18:56-00:19:42).
} 
Mela, M./ S. Köser (2017), Polish and German feedback signals in dyadic interactions: A culturological and phonetic analysis, (w:) Lingwistyka Stosowana/ Applied Linguistics/ Angewandte Linguistik (w druku).

Wieczorkiewicz, B. (1977), Sztuka mówienia: Poradnik. Warszawa.

Ośrodek Rozwoju Edukacji (b.r.), Emisja głosu.

(www.google.pl/url? sa $=\mathrm{i} \& \mathrm{rct}=\mathrm{j} \& \mathrm{q}=\& \mathrm{esrc}=\mathrm{s} \&$ source $=$ images $\& \mathrm{~cd}=\& v e d=0 \mathrm{ahUK}$ EwjVrofnqKrPAhVKOpoKHX6JBr0QjhwIAw\&url=https\%3A\%2F\%2Fzasobyi p2.ore.edu.pl\%2Fpl\%2Fpublications\%2Fdownload\%2F9571\&bvm=bv.1337005 28,d.bGs\&psig=AFQjCNGFt7OihQ_vQPQHUdQGvAJ781fNUw\&ust=1474885 919840968; pobrano 25.08.2016).

Instytut Medycyny Pracy im. Prof. J. Nofera (2005), Program Emisji Głosu. (http://old.imp.lodz.pl/emisja_glosu/FMain.html; Pobrano 25.08.2016).

Selting, M./ P. Auer/ D. Barth-Weingarten et al. (2009), Gesprächsanalytisches Transkriptionssystem 2 (GAT2), (w:) Gesprächsforschung - Online-Zeitschrift zur verbalen Interaktion 10/2009, 353-402. (http://www.gespraechsforschungozs.de/heft2009/px-gat2.pdf; pobrano 25.08.2016). 